\title{
Exogenous lactate is essential for metabolic activities in isolated rat spermatocytes and spermatids
}

\author{
Nicolet H. P. M. Jutte, J. A. Grootegoed, F. F. G. Rommerts and \\ H. J. van der Molen \\ Department of Biochemistry (Division of Chemical Endocrinology), Medical Faculty, \\ Erasmus University, Rotterdam, The Netherlands
}

\begin{abstract}
Summary. Spermatocytes and round spermatids were isolated from rat testis and the effects of addition of $3.3 \mathrm{~mm}$-glucose and $6 \mathrm{~mm}$-DL-lactate to the incubation medium on the morphology, oxygen consumption and incorporation of uridine and amino acids of these cells were investigated. Addition of lactate to isolated germ cells increased $\mathrm{O}_{2}$ consumption 1.8-fold and incorporation of precursors of RNA and protein by at least 5 -fold. The amino acid incorporation into spermatocytes and spermatids was irreversibly decreased after a preincubation for at least $5 \mathrm{~h}$ or $70 \mathrm{~min}$ respectively in the absence of lactate, indicating degeneration of the germ cells. In the presence of lactate, however, spermatocytes maintained their morphological integrity for at least $24 \mathrm{~h}$. Addition of glucose to isolated germ cells had no effect on any of the parameters investigated. It is concluded that isolated spermatocytes and round spermatids may utilize lactate, perhaps secreted by Sertoli cells, as the main source of energy.
\end{abstract}

\section{Introduction}

Germ cells in mammalian testes develop in a tubular environment which is controlled to a high degree by Sertoli cells. It is still unknown, however, which Sertoli cell products are important for germ cells. Glucose is known to be very important for the survival of germ cells in the testis. Inhibition of glucose transport by injections of 5-thio-D-glucose (Zysk, Bushway, Whistler \& Cariton, 1975; Lobl \& Porteus, 1978; Basu, Ramakrishnan, Prasannan, Rama Sarma \& Sundaresan, 1979; Majumdar et al., 1979; Majumdar \& Udelsman, 1979) and induction of acute hypoglycaemia (Mancini, Penhos, Izquierdo \& Heinrich, 1960) result in degeneration of germ cells. In isolated testicular tissue from adult rats, the addition of glucose to the incubation medium resulted in increased RNA synthesis (Hollinger \& Hwang, 1972), protein synthesis (Means \& Hall, 1968b; Davis, 1969; Hollinger \& Hwang, 1972), ATP levels (Means \& Hall, 1968a) and oxygen consumption (Tepperman, Tepperman \& Dick, 1949; Serfaty \& Boyer, 1956; Gomes, 1971). Testicular protein synthesis was increased 7-fold by glucose while in 16 other tissues from adult rats the stimulation was less than 1.5 times (Davis, 1969). Radioautographic analysis of testicular tissue incubated with $\left[{ }^{3} \mathrm{H}\right]$ lysine has shown that addition of glucose increases especially incorporation of this precursor into protein of pachytene spermatocytes and spermatids (Davis, 1969). No effects of glucose on metabolic activities in testicular tissue have been observed, however, when the number of germ cells was low, as in immature rats (Means \& Hall, 1968a, b), following hypophysectomy (Means \& Hall, 1968b) or after induction of experimental cryptorchidism (Davis, 1969; Gomes, 1971). Hence, it was concluded that pachytene spermatocytes and spermatids are most dependent on a proper supply of glucose. On the other hand, the effect of glucose on isolated spermatocytes 
and spermatids is small, i.e. approximately 1.5 -fold stimulation of amino acid incorporation (Nakamura \& Hall, 1976, 1977; Nakamura, Romrell \& Hall, 1978). These results suggest a discrepancy between the effects of glucose on germ cells in vivo and in vitro. In our experiments we observed a pronounced positive effect of lactate and pyruvate on isolated germ cells in media containing glucose. Therefore, we have studied the effects of glucose and lactate on different metabolic activities in isolated germ cells.

\section{Materials and Methods}

\section{Cell isolation}

Germ cell suspensions were prepared enzymically from testicular tissue of immature rats (Wistar strain, substrain R-Amsterdam, age 30-35 days, body weight 70-80 g) (Romrell, Bellvé \& Fawcett, 1976; Bellvé et al., 1977a; Bellvé, Millette, Bhatnagar \& O'Brien, 1977b). Pachytene spermatocytes and round spermatids were isolated by velocity sedimentation of the cell suspensions in non-linear albumin gradients $(1.0-3 \cdot 2 \%)$ at unit gravity during $70 \mathrm{~min}$ at room temperature (Grootegoed, Grollé-Hey, Rommerts \& · van der Molen, 1977). Cells were counted in a haemocytometer. Isolation medium and incubation medium were essentially Hanks' Balanced Salt Solution (Hanks \& Wallace, 1949) and Eagle's Minimal Essential Medium (Flow Laboratories Ltd, Irvine, Ayrshire, Scotland, U.K.). Both media were modified with an increased amount of $\mathrm{KCl}(56.9 \mathrm{~mm})$ and the osmolarity was adjusted by lowering the $\mathrm{NaCl}$ concentration (Grootegoed et al., 1977). The isolation medium was supplemented with $6 \mathrm{~mm}$ sodium-DL-lactate (Sigma; $50 \%$ L-lactate). When indicated in the text, lactate and/or glucose were added to the incubation medium to a final concentration of $6 \mathrm{~mm}$-DL-lactate and $3.3 \mathrm{~mm}$ glucose.

Sertoli cells were obtained from 26-day-old rats which had been irradiated in utero on Day 19 of gestation with $150 \mathrm{rad}$ (Beaumont, 1960). As a result of this treatment the testes were depleted of germ cells. Testes of these irradiated rats were treated with collagenase $(0.5 \mathrm{mg} / \mathrm{ml})$ during $20 \mathrm{~min}$ at $32^{\circ} \mathrm{C}$ to obtain tubules free from myoid and interstitial cells. These tubules were fragmented with a Dounce homogenizer (Fritz, Rommerts, Louis \& Dorrington, 1976). All cells were incubated at $32^{\circ} \mathrm{C}$.

\section{$R N A$ and protein synthesis}

Isolated germ cells were incubated in the incubation medium described above, containing labelled precursors for RNA and protein, during $2 \mathrm{~h}$ at $32^{\circ} \mathrm{C}$ under a humidified atmosphere of $5 \% \mathrm{CO}_{2}$ in air. On several occasions incubation with radioactively labelled precursors was preceded by a preincubation in the absence of this radioactivity. The incubations were stopped by cooling to $4^{\circ} \mathrm{C}$ and addition of cold $0.9 \%(\mathrm{w} / \mathrm{v}) \mathrm{NaCl}$ with either $0.5 \mathrm{~mm}$-uridine and $7 \mathrm{mM}$ leucine or $6.7 \mathrm{~mm}$-methionine. Cells were filtered over $0.2 \mu \mathrm{m}$ filters (Sartorius) and washed with $0.9 \%(\mathrm{w} / \mathrm{v}) \mathrm{NaCl}$. Subsequently the cells were lysed and macromolecules were precipitated with $10 \%(\mathrm{w} / \mathrm{v})$ trichloroacetic acid for $10 \mathrm{~min}$. The precipitate was washed with $10 \%(\mathrm{w} / \mathrm{v})$ trichloroacetic acid, to remove non-incorporated precursor, and then with $70 \%(\mathrm{v} / \mathrm{v})$ ethanol. The precipitate was dissolved in $500 \mu 11 \mathrm{M}-\mathrm{NaOH}$ and radioactivity in the samples was counted after addition of $8 \mathrm{ml}$ Picofluor (Packard).

\section{Oxygen consumption}

Isolated germ cells were incubated in phosphate-buffered saline (Dulbecco \& Vogt, 1954), supplemented with vitamins and amino acids as present in the incubation medium and, when indicated in the text, $6 \mathrm{~mm}$-DL-lactate and/or $3.3 \mathrm{~mm}$-glucose were added. Oxygen consumption was measured in a Warburg apparatus (Umbreit, Burris \& Stauffer, 1964). 


\section{Results}

The morphology (examined with phase-contrast microscopy) of isolated spermatocytes incubated for $24 \mathrm{~h}$ in a medium containing $3.3 \mathrm{~mm}$-glucose and $6 \mathrm{~mm}$-DL-lactate or $1 \mathrm{~mm}$ pyruvate, was very similar to that of freshly isolated germ cells. In contrast, the cells cultured without added lactate were degenerate, with translucent cytoplasm and clumped chromatin. Isolated spermatids cultured without lactate became degenerate after several hours. Isolated spermatocytes and spermatids therefore appear to require lactate more than glucose.

The effect of lactate was also demonstrated in short-term experiments. Lactate stimulated oxygen consumption of freshly isolated spermatocytes and spermatids both in the presence and absence of glucose (Text-fig. 1). Lactate had no significant effect, however, on the oxygen consumption of Sertoli cells. Uridine and leucine incorporation into isolated spermatocytes and spermatids was increased at least 5 -fold by the addition of lactate, whereas glucose had no significant effect (Table 1). This effect was demonstrated after 60 min preincubation with lactate. In Sertoli cells, addition of lactate with or without glucose caused a 2 -fold maximal stimulation of leucine incorporation.

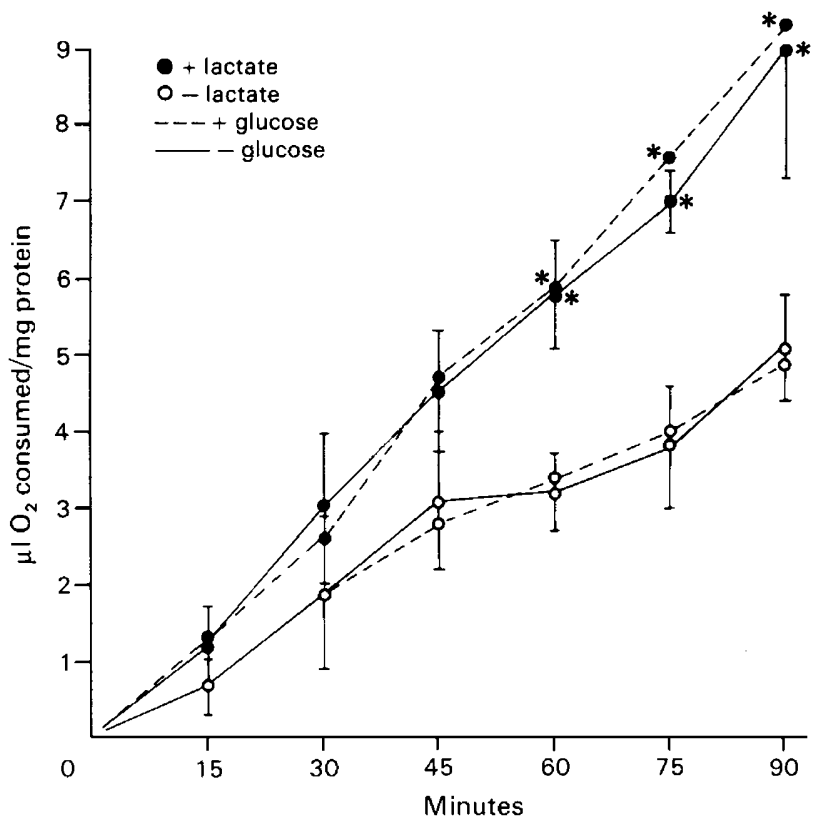

Text-fig. 1. The oxygen consumption by isolated germ cells ( $37 \%$ spermatocytes, $53 \%$ round spermatids, $4 \%$ other germ cells and $6 \%$ somatic cells) from rat testes incubated with (---) or without $(-)$ glucose and with $(\bullet)$ or without $(O)$ lactate. The values are the means obtained with 4 different cell preparations, and vertical bars indicate the s.d. ${ }^{*}$ Significantly different from values without lactate, $P<0.01$ (Student's $t$ test).

Incubation of germ cells in the absence of lactate for short periods did not cause an irreversible change of the capacity to incorporate amino acids. However, after a preincubation period without lactate of at least $5 \mathrm{~h}$ and $70 \mathrm{~min}$ for spermatocytes and spermatids respectively, the incorporation of methionine was not restored after addition of lactate (Table 2 ). 
Table 1. Incorporation of $\left[{ }^{3} \mathrm{H}\right]$ uridine and $\left[{ }^{14} \mathrm{C}\right]$ leucine into isolated germ cells from rat testes

\begin{tabular}{cccc}
\hline \multicolumn{2}{c}{ Substrate in incubation medium } & \multicolumn{2}{c}{ Incorporation } \\
\cline { 4 - 5 } 3.3 mM-glucose & $\begin{array}{c}\text { 6 mM-DL- } \\
\text { lactate }\end{array}$ & $\begin{array}{c}{\left[{ }^{3} \mathrm{H}\right] \text { Uridine }} \\
\left(\mathrm{nCi} / 10^{6} \text { cells }\right)\end{array}$ & $\begin{array}{c}{\left[{ }^{14} \mathrm{C}\right] \text { Leucine }} \\
\left(\times 10^{-1} \mathrm{nCi} / 10^{6} \text { cells }\right)\end{array}$ \\
\hline- & - & $5 \cdot 5 \pm 3 \cdot 6$ & $1.3 \pm 1 \cdot 0$ \\
+ & - & $21.8 \pm 15 \cdot 5$ & $2 \cdot 0 \pm 1 \cdot 6$ \\
- & + & $91.8 \pm 24 \cdot 5^{*}$ & $17.4 \pm 7 \cdot 2^{*}$ \\
+ & + & $125.5 \pm 50.9^{*}$ & $20 \cdot 3 \pm 6.7^{*}$ \\
\hline
\end{tabular}

The $5 \times 10^{5}$ cells $(55-88 \%$ spermatocytes, $1-23 \%$ round spermatids, 9-15\% other germ cells and $2-9 \%$ somatic cells) were incubated for $2 \mathrm{~h}$ in $1 \mathrm{ml}$ incubation medium containing $5 \mu \mathrm{Ci}\left[5-{ }^{3} \mathrm{H}\right]$ uridine (final sp. act. $5 \mathrm{mCi} / \mathrm{mmol}$ ) and $0.6 \mu \mathrm{Ci} \mathrm{L}-\left[\mathrm{U}-{ }^{14} \mathrm{C}\right]$ leucine (final sp. act. $12 \mathrm{mCi} / \mathrm{mmol}$ ) after preincubation for $60 \mathrm{~min}$. Radioactivity in trichloroacetic acidprecipitable material was estimated. Values are mean \pm s.d. obtained with 4 different cell preparations.

* Significantly different from incorporation in the absence of glucose and lactate, $P<0.01$ (paired Student's $t$ test).

Table 2. Effect of preincubation without lactate on incorporation of methionine into isolated germ cells from rat testes

\begin{tabular}{|c|c|c|c|}
\hline \multicolumn{2}{|c|}{ Lactate in medium } & \multicolumn{2}{|c|}{$\begin{array}{l}{\left[{ }^{35} \mathrm{~S}\right] \text { Methionine incorporation }} \\
\left(\mathrm{nCi} / 10^{6} \text { cells }\right)\end{array}$} \\
\hline Preincubation* & Incubation & Spermatocytes & Spermatids \\
\hline - & - & $5 \cdot 7 \pm 4 \cdot 0$ & $0.8 \pm 0.3$ \\
\hline- & + & $18.8 \pm 6.6$ & $2.8 \pm 1.0$ \\
\hline+ & + & $31.6 \pm 10 \cdot 7$ & $4 \cdot 9 \pm 2 \cdot 1$ \\
\hline
\end{tabular}

The $5 \times 10^{5}$ cells of a spermatocyte fraction $(80 \%$ spermatocytes, $6-8 \%$ round spermatids, $8-12 \%$ other germ cells and $4-5 \%$ somatic cells) or $10^{6}$ cells from a spermatid fraction (15$20 \%$ spermatocytes, $70-76 \%$ round spermatids, $6-9 \%$ other germ cells and $1-4 \%$ somatic cells) were incubated for $2 \mathrm{~h}$ in $200 \mu \mathrm{l}$ incubation medium containing $10 \mu \mathrm{Ci} \mathrm{L}-\left[{ }^{33} \mathrm{~S}\right]$ methionine (final sp. act. $20 \mathrm{Ci} / \mathrm{mmol}$ ) in tubes shaken at 120 oscillations $/ \mathrm{min}$. The incubation medium contained $3.3 \mathrm{~mm}$-glucose and, as indicated, $6 \mathrm{~mm}$-DL-lactate. Values are mean \pm s.d. for 3 different cell preparations.

* 5-7 $\mathrm{h}$ for spermatocytes and $70-90 \mathrm{~min}$ for spermatids.

\section{Discussion}

The present results show that in germ cells isolated from rat testes exogenous lactate is needed for metabolic activities, as shown by oxygen consumption and RNA and protein synthesis. The effects of the absence of lactate were immediate and were measurable in short-term incubations. When the germ cells were incubated in the absence of lactate for several hours, the decreased metabolic activity was not completely restored after addition of lactate and therefore the cells appear to have degenerated. Degeneration of isolated spermatocytes and round spermatids was readily apparent with phase-contrast microscopy after an incubation without lactate for $24 \mathrm{~h}$. A small percentage of Sertoli cells was always present in our germ cell preparations, but the effects of addition of lactate to germ cell cultures could not be ascribed to contaminating Sertoli cells. 
The present observations are very relevant for investigations with male germ cells in vitro. The isolation and incubation of these cells have been performed by many investigators using media that did not contain lactate or pyruvate. For example, protein synthesis in isolated germ cells (Nakamura et al. 1978) and permeability of the plasma membrane of isolated germ cells (Lee, 1974) have been measured at $32^{\circ} \mathrm{C}$ and $37^{\circ} \mathrm{C}$ in media which contained no other substrate than glucose. It is very likely that the observations made in these experiments were markedly influenced by degeneration of the germ cells due to the absence of a proper substrate.

The fact that glucose cannot support metabolic activities of germ cells may be due either to a block in glucose transport or to a block in glycolysis and the hexose monophosphate shunt. It has been demonstrated that the $\mathrm{X}$ chromosome is inactive throughout meiotic prophase (Monesi, 1965) and therefore the specific activity of the X-linked iso-enzyme of the glycolytic enzyme phosphoglycerate kinase (PGK) in germ cells may be rather low. It is not possible to conclude, however, that a block in glycolysis in germ cells is caused by the fact that PGK is X-linked because an autosome-linked PGK iso-enzyme, present in testicular tissue, is probably active in spermatocytes and spermatids (VandeBerg, Cooper \& Close, 1973, 1976). Similarly, the enzyme glucose-6-phosphate dehydrogenase is X-linked, but a block of the hexose monophosphate shunt in germ cells may be prevented by the activity in these cells of an autosomally coded iso-enzyme demonstrated in testicular tissue (Brock, 1977). There is no definite proof, however, that the enzymes mentioned above or other enzymes involved in glucose metabolism are fully active in spermatocytes and spermatids. It is, therefore, still possible that glucose metabolism is blocked in these cells by inactivity of these enzymes. However, protein synthesis in isolated spermatocytes is not inhibited by the presence of 5-thioD-glucose (Nakamura \& Hall, 1977), an inhibitor of transport of D-glucose (Whistler \& Lake, 1972). This observation supports the idea that spermatocytes do not depend on an active glucose transport mechanism.

In pachytene spermatocytes and in spermatids a specific iso-enzyme of lactate dehydrogenase (LDH-X) is present (Meistrich, Trostle, Frapart \& Erickson, 1977). It has been shown that testicular LDH-X catalyses preferentially lactate oxidation and is localized in cytosol and mitochondria (Blanco, Burgos, Gerez de Burgos \& Montamat, 1976; Montamat \& Blanco, 1976). This, as well as the localization of mitochondria in early round spermatids close to the cell surface (Clermont \& Rambourg, 1978), may indicate that germ cells are specialized to use exogenous lactate efficiently. Spermatocytes in contact with Sertoli cells in cultures of seminiferous tubule fragments can survive for more than 5 days in a medium with glucose and without lactate (Palombi et al., 1979). The survival of germ cells in this system may be explained by the secretion of lactate by Sertoli cells, because we have observed lactate production by Sertoli cells in culture $(2.2 \pm 0.8 \mu \mathrm{mol} / \mathrm{mg}$ protein per day). The effects of glucose on testicular tissue (see 'Introduction') may therefore largely reflect a stimulation of germ cells by lactate produced by Sertoli cells.

The dependence of male germ cells on Sertoli cells is not unique, because a similar relation exists between female germ cells and follicular cells. Granulosa cells have been shown to produce pyruvate (Donahue \& Stern, 1968). Isolated mouse and rat oocytes use pyruvate or lactate as an energy source (Biggers, Whittingham \& Donahue, 1967; Zeilmaker \& Verhamme, 1974; Hillensjö, Hamberger \& Ahrén, 1975; Eppig, 1976), but growing oocytes can survive in the absence of pyruvate when cultured in the presence of follicular granulosa cells (Baran \& Bachvarova, 1977; Eppig, 1977; Bachvarova, Baran \& Tejblum, 1980). It remains to be demonstrated whether lactate and/or pyruvate represent an important intermediate for the interaction between Sertoli cells or granulosa cells and germ cells in vivo.

We thank Mrs L. M. Koolen-van Meerkerk and Mr R. Jansen for expert technical assistance and Miss W. Bakhuizen for the help in the preparation of this manuscript. This work was supported in part by the Dutch Foundation for Medical Research (FUNGO). 


\section{References}

Bachvarova, R., Baran, M.M. \& Tejblum, A. (1980) Development of naked growing mouse oocytes in vitro. J. exp. Zool. 211, 159-169.

Baran, M.M. \& Bachvarova, R. (1977) In vitro culture of growing mouse oocytes. $J$. exp Zool. 202, 283-289.

Basu, S.L., Ramakrishnan, S., Prasannan, K.G., Rama Sarma, P.R. \& Sundaresan, R. (1979) Reversible sterility due to diminished glucose metabolism in male mice treated with 5 thio-Dglucose. Ind. J. exp. Biol. 17, 632-636.

Beaumont, H.M. (1960) Changes in the radiosensitivity of the testis during foetal development. Int. $J$. Radiat. Biol. 2, 247-256.

Bellvé, A.R., Cavicchia, J.C., Millette, C.F., O'Brien, D.A., Bhatnagar, Y.M. \& Dym, M. (1977a) Spermatogenic cells of the prepuberal mouse. Isolation and morphological characterization. $J$. Cell Biol. 74, 68-85.

Bellvé, A.R., Millette, C.F., Bhatnagar, Y.M. \& O'Brien, D.A. (1977b) Dissociation of the mouse testis and characterization of isolated spermatogenic cells. J. Histochem. Cytochem. 257, 480-494.

Biggers, J.D., Whittingham, D.G. \& Donahue, R.P. (1967) The pattern of energy metabolism in the mouse oocyte and zygote. Proc. natn. Acad. Sci. U.S.A. 58, 560-567.

Blanco, A., Burgos, C., Gerez de Burgos, N.M. \& Montamat, E.E. (1976) Properties of the testicular lactate dehydrogenase isoenzyme. Biochem. J. 153, $165-172$.

Brock, W.A. (1977) Evidence against gene expression after meiosis in the male mouse. J. exp. Zool. 202, 69-80.

Clermont, Y. \& Rambourg, A. (1978) Evolution of the endoplasmatic reticulum during rat spermiogenesis. Am. J. Anat. 151, 191-212.

Davis, J.R. (1969) Metabolic aspects of spermato genesis. Biol. Reprod. 1, 93-118.

Donahue, R.P. \& Stern, S. (1968) Follicular cell support of oocyte maturation: production of pyruvate in vitro. J. Reprod. Fert. 17, 395-398.

Dulbecco, R. \& Vogt, M. (1954) Plaque formation and isolation of pure lines with poliomyelitis viruses. J. exp. Med. 99, 167-182.

Eppig, J.J. (1976) Analysis of mouse oogenesis in vitro. Oocyte isolation and the utilization of exogenous energy sources by growing oocytes. J. exp. Zool. 198, 375-382.

Eppig, J.J. (1977) Mouse oocyte development in vitro with various culture systems. Devl Biol. 60, 371-388.

Fritz, I.B., Rommerts, F.F.G., Louis, B.G. \& Dorrington, J.H. (1976) Regulation by FSH and dibutyryl cyclic AMP of the formation of androgenbinding protein in Sertoli cell-enriched cultures. J. Reprod. Fert. 46, 17-24.

Gomes, W.R. (1971) Oxygen consumption by seminiferous tubules and interstitial tissues of normal and cryptorchid rat testes. J. Reprod. Fert. 26, 427429.

Grootegoed, J.A., Grollé-Hey, A.H., Rommerts, F.F.G. \& van der Molen, H.J. (1977) Ribonucleic acid synthesis in vitro in primary spermatocytes isolated from rat testis. Biochem. J. 168, 23-31.

Hanks, J.H. \& Wallace, R.E. (1949) Relation of oxygen and temperature in the preservation of tissues by refrigeration. Proc. Soc. exp. Biol. Med. 71, 196200.

Hillensjö, T., Hamberger, L. \& Ahrén, K. (1975) Respiratory activity of oocytes isolated from ovarian follicles of the rat. Acta endocr., Copenh. 78, 751-759.

Hollinger, M.A. \& Hwang, F. (1972) Effect of puromycin and actinomycin D on glucose-stimulated protein and RNA labelling, in vitro, in rat testis. Biochim. biophys. Acta 262, 336-343.

Lee, L.P.K. (1974) Temperature effect on the permeability of plasma membranes of advanced germinal cells of the rat testis. Can. J. Biochem. 52, 586593.

Lobl, T.J. \& Porteus, S.E. (1978) Antifertility activities of 5-thio-D-glucose in mice and rats. Contraception 17, 123-130.

Majumdar, S.K. \& Udelsman, R. (1979) Fine structure of mouse testes following intraperitoneal treatment with 5-thio-D-glucose. J. Hered. 70, 194-198.

Majumdar, S.K., Brady, K.D., Ringer, L.D., Natoli, J., Killian, C.M., Portnoy, J.A. \& Koury, P. (1979) Reproduction and teratogenic studies of 5-thio-Dglucose in mice. $J$. Hered. 70, 142-145.

Mancini, R.E., Penhos, J.C., Izquierdo, I.A. \& Heinrich, J.J. (1960) Effects of acute hypoglycemia on rat testis. Proc. Soc. exp. Biol. Med. 104, 699-702.

Means, A.R. \& Hall, P.F. (1968a) Protein biosynthesis in the testis: II. Role of adenosine triphosphate (ATP) in stimulation by glucose. Endocrinology 83, 86-96.

Means, A.R. \& Hall, P.F. (1968b) Protein biosynthesis in the testis. I. Comparison between stimulation by FSH and glucose. Endocrinology 82, 597-602.

Meistrich, M.L., Trostle, P.K., Frapart, M. \& Erickson, R.P. (1977) Biosynthesis and localization of lactate dehydrogenase $\mathrm{X}$ in pachytene spermatocytes and spermatids of mouse testes. Devl Biol. 60, 428441.

Monesi, V. (1965) Synthetic activities during spermatogenesis in the mouse. Expl Cell Res. 39, 197-224.

Montamat, E.E. \& Blanco, A. (1976) Subcellular distribution of the lactate dehydrogenase isozyme specific for testis and sperm. Expl Cell Res. 103, 241-245.

Nakamura, M. \& Hall, P.F. (1976) Inhibition by 5thio-D-glucopyranose of protein biosynthesis in vitro in spermatids from rat testis. Biochim. biophys. Acta 447, 474-483.

Nakamura, M. \& Hall, P.F. (1977) Effect of 5-thio-D glucose on protein synthesis in vitro by various types of cells from rat testes. J. Reprod. Fert. 49, 395397.

Nakamura, M., Romrell, L.J. \& Hall, P.F. (1978) The effects of temperature and glucose on protein biosynthesis by immature (round) spermatids from rat testes. J. Cell Biol. 79, 1-9.

Palombi, F., Ziparo, E., Rommerts, F.F.G., Grootegoed, J.A., Antonini, M. \& Stefanini, M. (1979) Morpho- 
logical characteristics of male germ cells of rats in contact with Sertoli cells in vitro. J. Reprod. Fert. 57, 325-330.

Romrell, L.J., Bellvé, A.R. \& Fawcett, D.W. (1976) Separation of mouse spermatogenic cells by sedimentation velocity. A morphological characterization. Devl Biol. 19, 119-131.

Serfaty, A. \& Boyer, J. (1956) l'Influence de divers métabolites glucidiques sur l'intensité respiratoire du testicule de rat blanc. Experientia 12, 386-387.

Tepperman, J., Tepperman, H.M. \& Dick, H.J. (1949) A study of the metabolism of rat testis in vitro. Endocrinology 45, 491-503.

Umbreit, W.W., Burris, R.H. \& Stauffer, J.F. (1964) Manometric Techniques, 4th edn. Burgess Publ. Co., Minnesota.

VandeBerg, J.L., Cooper, D.W. \& Close, P.J. (1973)
Mammalian testis phosphoglycerate kinase. Nature, New Biol. 243, 48-50.

VandeBerg, J.L., Cooper, D.W. \& Close, P.J. (1976) Testis specific phosphoglycerate kinase B in mouse. J. exp. Zool. 198, 231-240.

Whistler, R.L. \& Lake, W.C. (1972) Inhibition of cellular transport by 5-thio-D-glycopyranose. Biochem. J. 130, 919-925.

Zeilmaker, G.H. \& Verhamme, C.M.P.M. (1974) Observations on rat oöcyte maturation in vitro: morphology and energy requirements. Biol. Reprod. $11,145-152$.

Zysk, J.R., Bushway, A.A., Whistler, R.L. \& Carlton, W.W. (1975) Temporary sterility produced in male mice by 5-thio-D-glucose. J. Reprod. Fert. 45, 69-72.

Received 28 July 1980 